\title{
Academy-profession-market. Problematising tensions in the live project
}

\author{
Michael Davis \\ University of Auckland, New Zealand \\ School of Architecture and Planning \\ m.davis@auckland.ac.nz
}

\begin{abstract}
This paper examines a form of "live project" that casts the design studio topic in three distinct roles. In one guise it is a collaborative, "real world," engagement with a range of stakeholders. In another it presses toward the production of buildings, while in a third, it acts as the vehicle for higher level academic design research. Within the design studio at the University of Auckland, School of Architecture and Planning these three imperatives are juxtaposed to define the contested territory from which the architectural project emerges as negotiated, speculative-yet-realisable outcome.

The aim of this discussion is to demonstrate the triple focus model of live project and the problem currently confronting it: a local instance of a complex, widespread problem between the architectural academy, the profession and the market.

Since 2007 a succession of community groups, businesses and developers have brought their projects to the design studio at the school. Typically they have come looking for speculation as to the potential of their projects, the kind of breadth of exploration that generally is not viable within commercial architectural organisations. Meanwhile, through these projects, students are asked to conduct research into the development of their own critical, architectural making practices.

The text begins with an account of one particular project - a speculation as to the development opportunities of heritage buildings on "earthquake prone" sites in Auckland for one of the country's most progressive developers. It looks at the larger academic, professional and market conditions being responded to and thus situates this type of live project before concluding with an outline of potentials for its advancement. In so doing it signals work to come.
\end{abstract}

Keywords: architectural pedagogy, live project, design research, practice.

To cite this article:

Davis, M. (2017). Academy-profession-market. Problematising tensions in the live project. The Journal of Public Space, 2(3), Special Issue, 85-92, DOI: 10.5204/jps.v2i3.I I7

This article has been peer-reviewed and accepted for publication in The Journal of Public Space. Please see the Editorial Policies under the 'About' section of the journal website for further information.

This work is licensed under a Creative Commons Attribution - Non Commercial 4.0 International License https://creativecommons.org/licenses/by-nc/4.0/ 


\section{Introduction}

This paper reflects upon a form of "live project" that casts the design studio topic in three distinct roles. In one guise it is a collaborative, "real world," engagement with a range of stakeholders. In another it presses toward the production of buildings, while in a third, it acts as the vehicle for higher level academic design research. Within the design studio at the University of Auckland, School of Architecture and Planning, these three imperatives are juxtaposed to define the contested territory from which the architectural project emerges as negotiated, speculative-yet-realisable outcome.

Architectural design pedagogy is the focus here. The paper aims to present a "triple focus" model of live project and to set out the problem evidently currently confronting it: a local instance of a complex, widespread problem between the architectural academy, the profession and the market.I The hope in doing so is that the problem might be addressed in future projects. The text is narrative in manner and begins with an account of one particular project. It pulls back to examine the experience in relation to broader conditions and thus situates this type of live project. It concludes with an outline of potentials for its advancement and in so doing signals work to come.

The teaching model discussed is termed "live" because the projects have real clients, with real briefs, sites and deadlines. Sometimes they also have real money that brings with it the opportunity to realise projects in built form.

\section{The live project at the University of Auckland}

The University of Auckland's School of Architecture and Planning, offers a three year undergraduate Bachelor of Architectural Studies (BAS) followed by a professionally accredited, two year Master of Architecture Professional (MArch Prof). The studio-based design courses lie at the heart of our programmes. Different types of live project are framed and run as design courses as circumstances and opportunities permit at years 2 and 3 of the BAS and year I of the MArch(Prof).

Each year since 2007 we have run at least one that has focused on the potential procurement of a building. Clients have ranged from community groups, to government agencies, to small businesses, to developers. We aim to bring students into contact with these bodies and thus to foster relationships between the academy and what might be termed the "market." The purpose of doing so is not to overwhelm the students' ambitions, and not to make them "compliant" architects, but rather to normalise the tension between the development of their own practice and "real world" constraints. It also offers the rare chance for students to impact the built environment while still in formal education.

The work we provide our clients with builds impetus behind their projects and operates as a base for funding applications, community consultation and provocation for governing boards. To name the projects to date: Muriwai Surf Life Saving Club (2007), see figure I; Housing (4) New Zealand (2008); EcoTech (2009); Confucius Institute (20I0); Kaipatiki Project (20II); College Rifles Rugby Club (20I2); Akarana Golf Club (20I3); Fletcher Developments (semester I, 20I4). In the second semester of 2014 we ran a project for a developer who will be referred to here as the "Client."

\footnotetext{
' This paper develops from an earlier text. See Michael Davis, “Academy-Profession-Market: Confronting the Tension Through the Live Project" in Applied Collaborations, Proceedings from the 8th International Conference and Exhibition of the Association of Architecture Schools of Australasia (Christchurch, New Zealand, 2015).
} 


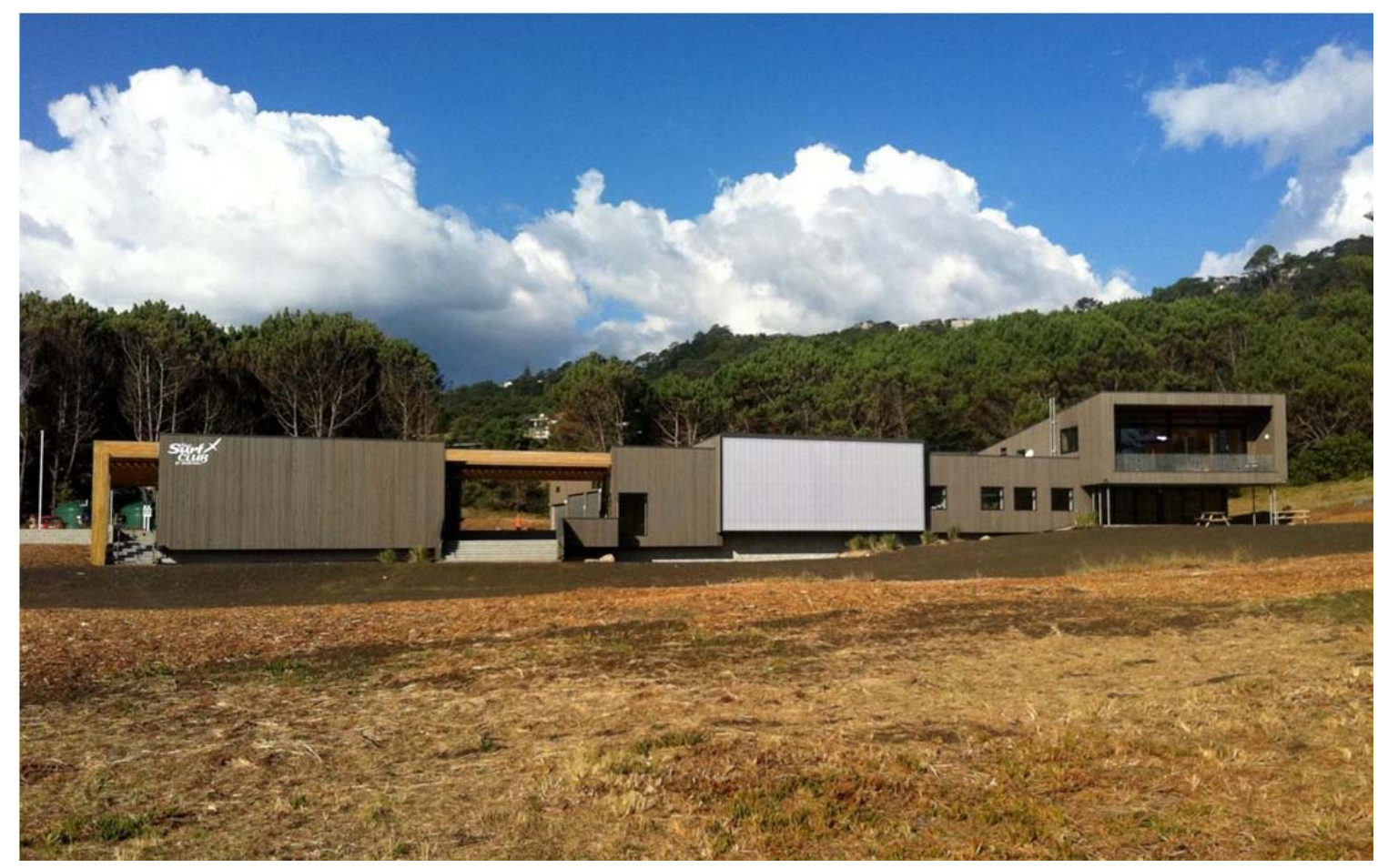

Figure I. Muriwai Surf Lifesaving Club, http://www.thesurfclubatmuriwai.org/wp-content/uploads 12013/08/IMG_4904.jpg, Photographer: Kath Moore.

It is fair to say that up until our encounter with the Client, this stream of the school's live project agenda had got itself into a sort of happy rut. It followed a well-developed path that delivered excellent learning outcomes for students and high quality design speculations for clients. The emotional upheaval that followed our semester 2, 2014 project shifted us.

\section{A project}

My colleague Alessandro Melis and I are academic-practitioners, meaning we remain active in architectural practice (including the realisation of buildings) in parallel to (and increasingly as part of) our academic roles. In semester two of 2014 we ran a design topic titled Through the Space of Representation. ${ }^{2}$ It brought 15 year 3 BAS students together with eight year I MArch(Prof) students to speculate as to the development opportunities presented by earthquake prone heritage buildings on 10 different sites scattered throughout the inner suburbs of Auckland. The Client was one of the country's most progressive developers.

\footnotetext{
${ }^{2}$ Michael Davis and Alessandro Melis, "Through the Space of Representation," Design Studio Topic Outline (Auckland: University of Auckland, School of Architecture and Planning, 20I4).
} 


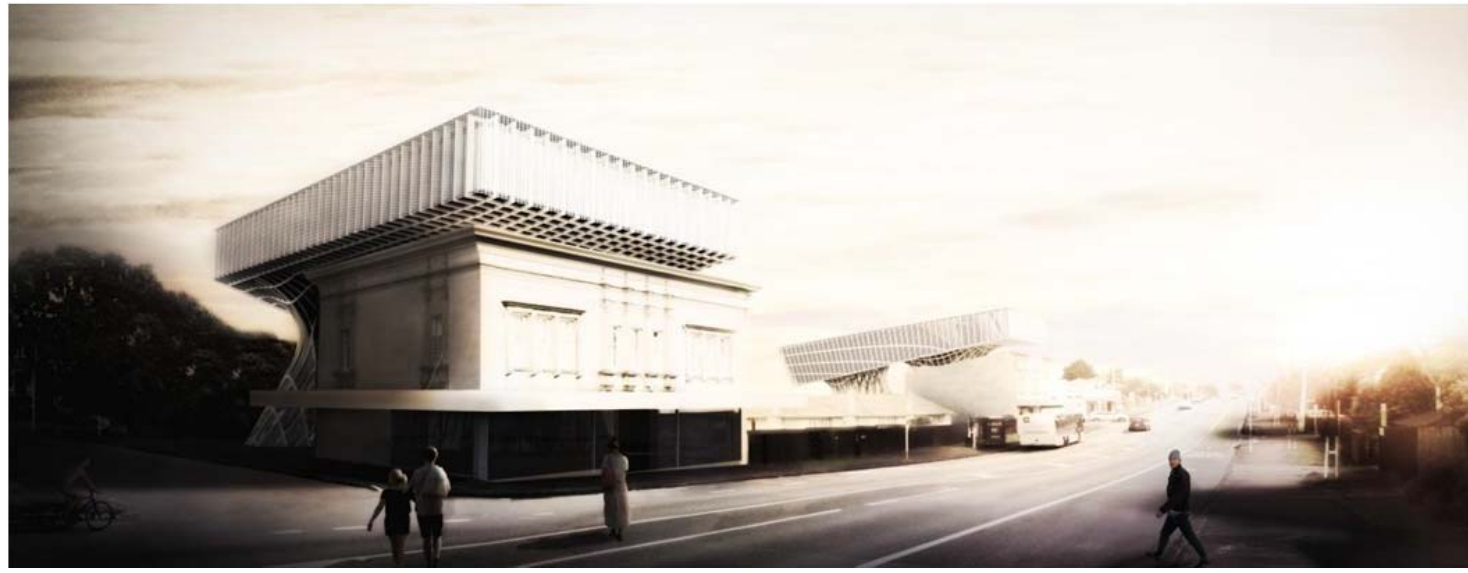

Figure 2. Liam Stumbles, 727-73I \& 767-77I Dominion Road - Dominion Road perspective.

\section{One Outcome}

Alessandro and I had the benefit of working with a number of excellent students on this live project, including Liam Stumbles (see figures 2-4). The Client became very excited about Liam's project, so excited that he took Liam's final presentation boards to his quantity surveyor. We were not included in any discussion around the pricing of the project and predictably, without the appropriate information, the quantity surveyor came back with an extremely conservative estimate. Despite that, the Client instigated a meeting to discuss Liam's project with Liam, Alessandro and me.

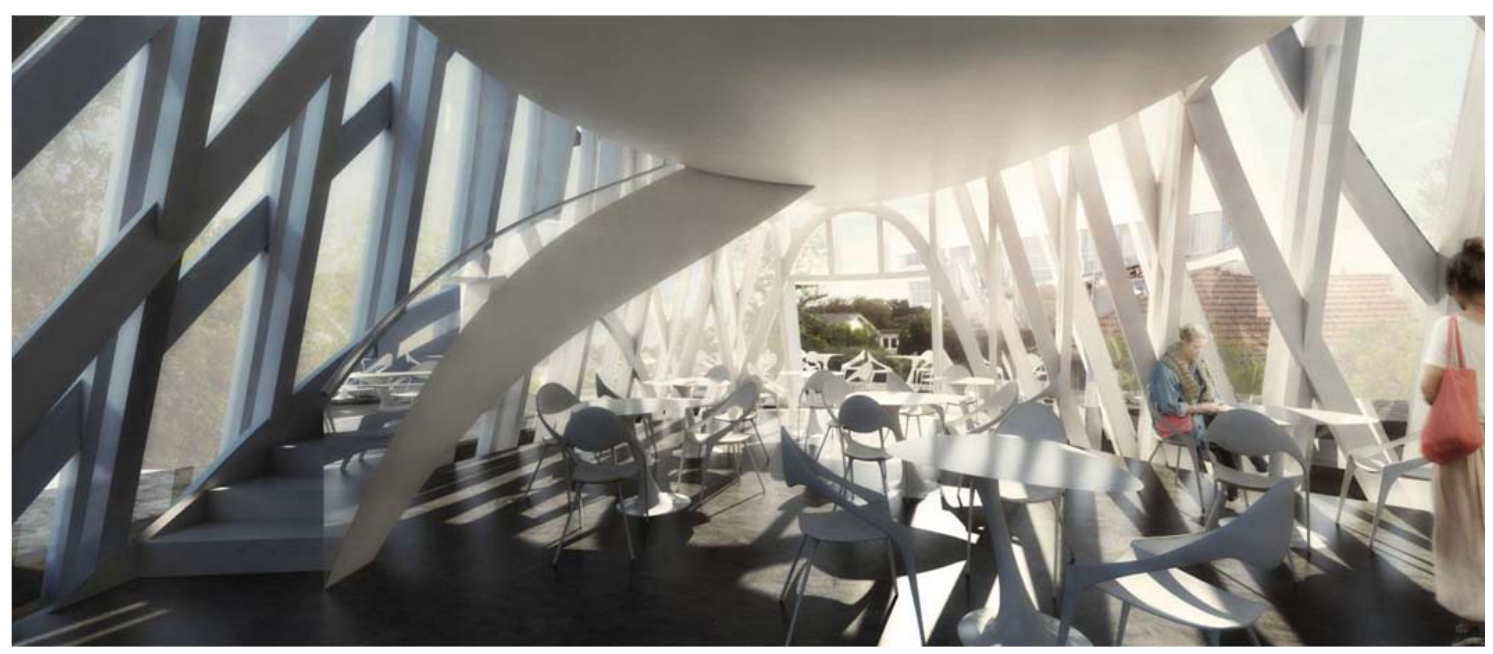

Figure 3. Liam Stumbles, 727-73I \& 767-77I Dominion Road - interior perspective.

Given that one aim of our live project was to bring the academy and the market into closer relation we were enthusiastic about the possibility of further developing Liam's proposal. For Alessandro and me it was an opportunity to carry out design research into the delivery of "non-standard" formal outcomes in a modest economy. For Liam it was to unfold as the first design thesis (year 2 of the MArch Prof) in the eight years of the programme that would focus on developed design and technical resolution of a formally complex building. 


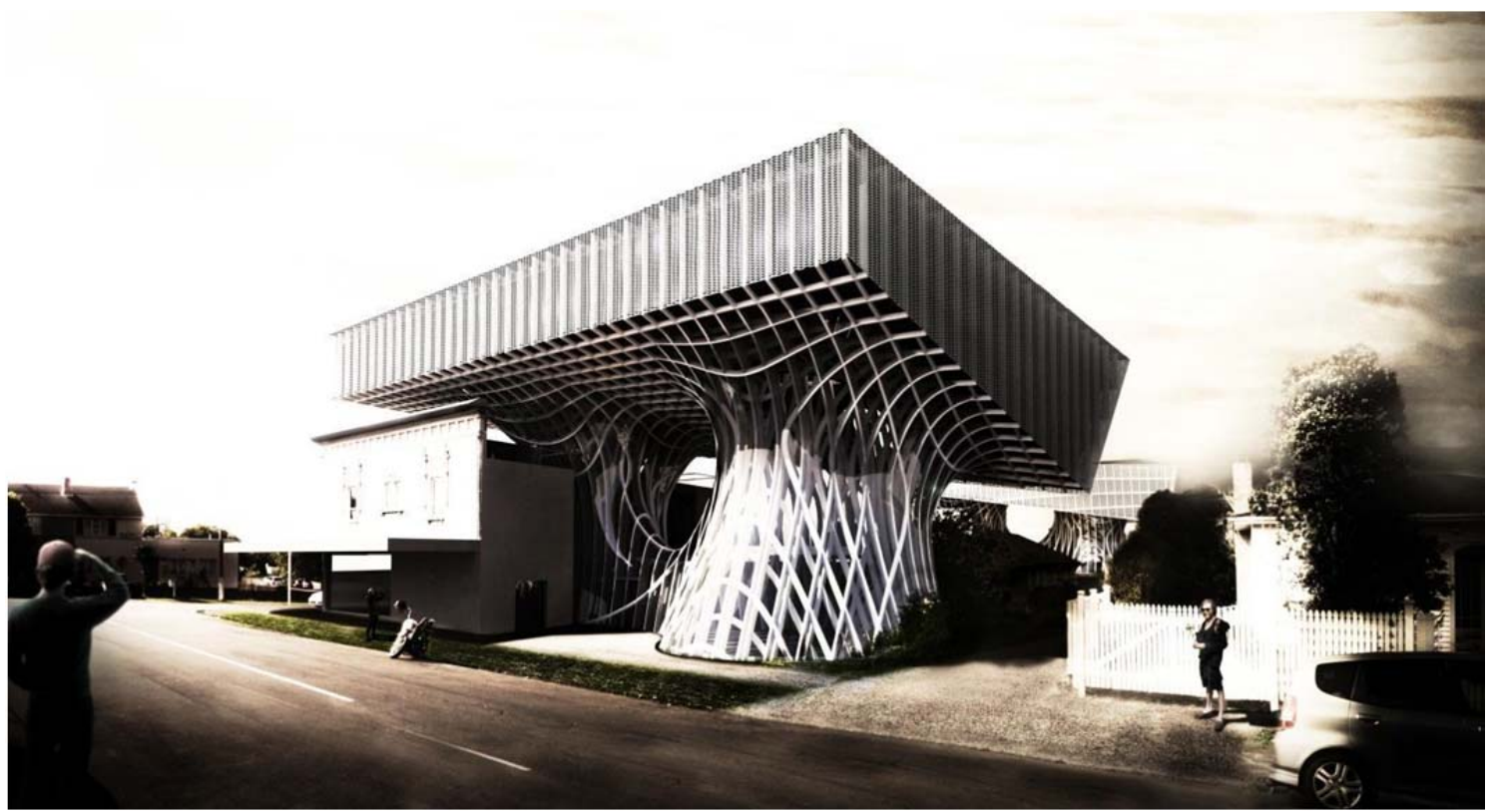

Figure 4. Liam Stumbles, 727-73I \& 767-77I Dominion Road - Halesowen Avenue perspective.

However, in the two weeks between the email I sent to arrange the meeting and when we actually sat down together, our Client's attitude had changed completely. During our meeting he conceded that on the back of the outlandish estimate he had received from his quantity surveyor, he had spoken to two of the architects he uses regularly. It became apparent that they had contributed to his change of heart.

\section{How did this happen?}

Could it be that we were dismissed by our solely-commercially-focused peers simply because of our association with academia? But the Client was in possession of material that demonstrated our experience and capacity to complete these kinds of formally speculative projects - we had done so overseas.

Were we dismissed due to the Client's lack of belief in our capability to deliver the kind of project he had been seeking through his brief to us in an Auckland context? But I have been located here for 14 of my 20 years in architectural practice.

Was it the "wild-ness" of the speculation? But this was the very thing that we were asked to deliver by the Client, the thing that drew us into this relationship in the first instance.

While all of these questions surfaced in some form or other during our conversation with the Client, the more Alessandro and I looked at it, the more it became clear that we had crossed some sort of line. Apparently, our role was only to speculate over this project and, in doing so, to give the Client and his architects a sense of current and future aesthetic flavours so as to give them some sort of competitive advantage in their respective markets. Our role was not to produce such compelling projects that the market share of our solely-commerciallyengaged colleagues would be threatened. Exposure to market forces indeed.

As we dwelt on this outcome a strong sense grew that this was evidence of something bigger; a problem that had been present throughout this stream of live projects that had found discernible, disturbing form in this instance. The experience catalysed a period of reflection and investigation that included the writing of this text. The aim was to situate this particular derivative of the live project, to see it through a wider lens and to articulate what it was 
confronting. Findings began with the realisation that we were dealing with three distinct parties - the academy, the market and the profession.

\section{Architectural pedagogy and the live project}

Internationally the live project is set in relation to a long history of tension in the discipline between the academy (which seeks a more critical engagement with the architectural discipline), the profession (which seeks a more pragmatic engagement with the differing material, economic and social forces that shape architecture) and the market (with its complexity of fluctuating demands) ${ }^{3}$. This problem is well documented in Mitgang and Boyer's 1996 report for the Carnegie Foundation for the Advancement of Teaching, titled Building Communities: A New Future for Architecture, Education and Practice. ${ }^{4}$ While focused on conditions in the USA and dated in certain respects, the report remains an accurate reflection of demonstrably enduring issues within the architectural discipline.

Every five years the University of Auckland's School of Architecture and Planning is visited by an accreditation panel consisting of international and national experts called a National Visiting Panel (NVP) who review the architecture programmes. They advise as to how we are performing and set goals which are followed through annually by an Interim Review Panel (IRP). Generally, the NVP brings local specificity to the issues Mitgang and Boyer raise in their report. These issues have persisted since the shift of architectural education from an apprenticeship system to a university degree structure, a shift that began in the early $20^{\text {th }}$ century (if not earlier). In other words, the issues raised by the NVP might often be seen to be symptomatic of a larger, persistent condition embedded within the discipline.

Various types of live project might be seen to attend to the concerns Mitgang and Boyer raise in differing ways. ${ }^{5}$ But their report applauds design and build type studios especially. Samuel Mockby's Rural Studio, while not mentioned by name in the report, is a well-known example of this sort of endeavour. 6 These studios address real projects often in socially and economically challenged communities both to meet immediate needs and to provide social and economic stimulation. Students do it all, grappling with every aspect of architectural production from design through to building their projects on site.

Our school, in 2007, was to establish its own design and build type programme around the Muriwai Surf Lifesaving Club project. However, it quickly became apparent that, due to institutional constraints - health and safety concerns, programme structure and the like - our ambition had to be reformed. Instead, we set up collaborative yet competitive proto-office conditions in the design studio. Each office ultimately had to demonstrate a highly resolved architectural proposition on the strongest terms available to it - from animations through to I:I detail prototypes. This set the standard for our live project agenda.

\footnotetext{
${ }^{3}$ It is worth noting that having also been exposed to these issues in Australia, Canada, the UK and the Netherlands, nowhere have I found the tension between parties to be as pronounced as in New Zealand. Here, practitioners (too) closely associated with the academy are marginalised as "academics" - in the current cultural climate being so engaged is viewed with puzzlement more than approval. We are notionally excluded from commercial endeavour by the profession and the market - we are not seen as being engaged with reality. It is also worth noting how distressing this situation is for those of us caught up in it because of concerns we share not just for ourselves but for the advancement of the discipline more generally.

${ }^{4}$ Ernest Boyer and Lee Mitgang, Building Communities: A New Future for Architecture, Education and Practice (Princeton: Carnegie Foundation for the Advancement of Teaching, 1996).

${ }^{5}$ For example, see the range of projects presented in Live Projects: Designing With People, ed. Esther Charlesworth, Melanie Dodd, and Fiona Harrisson (Melbourne: RMIT University Press, 20I2).

${ }^{6}$ See, for instance, Andrea Oppenheimer Dean and Timothy Hursley, Rural Studio: Samuel Mockbee and an Architecture of Decency (New York: Princeton Architectural Press, 2002).
}

90 | The Journal of Public Space, 2(3), 2017 | Special Issue | ISSN 2206-9658

(c) Queensland University of Technology 


\section{Outline of a professional condition}

To provide a sketch of the local professional environment within which the school's live project agenda has developed: over the course of the past twenty years the building industry in New Zealand has encountered significant change in terms of building regulation and costs. On top of an increasing range of competitors and the proliferation of specialist consultants, the impacts of issues such as the "leaky building crisis," the Christchurch earthquakes, Auckland Council's Unitary Plan and others have resulted in the architectural profession being shouldered with more work and more risk without comparable increases in fees. One celebrated Auckland architect also recently commented that over the past generation the amount of documentation required to submit a house for building consent has increased by a factor of up to eight, but the quality of the architecture has not improved to match. ${ }^{7}$

\section{Outline of a market condition}

The traditional role of the architect is to speculate, to document and to act as their clients' agent in the delivery of a built project. When so much more documentation is required within an overall fee that remains essentially unchanged, documentation absorbs the bulk, delivery retains some space, but speculation is squeezed right down. One might quickly surmise, then, that another reason our client bodies come to us is out of a desire for a speculative investigation of the potential their projects hold - the kind of broad design exploration that is not as viable within commercial operations as it is within an academic environment vested in asking "what if...?" type questions.

\section{Outline of an academic condition}

Against this background certain pedagogical complexities play out. The "resistance" design tutors sometimes encounter in students at the Auckland school is a particular issue. 8 Resistance is a learning impediment. Reasons for it are manifold. They might include fatigue and fear but may also include a student's sense of self-satisfaction at one extreme, to low levels of self-expectation in terms of their own abilities at the other. It is a quality of student performance that presents as a lack of willingness to take risks such as learning and applying a new software technique. Often, simultaneously, students will present crises of confidence in what they already know. Combined and unchecked this will amount to a kind of paralysis. Inside our live project we seek to break down resistance, to extend students' repertoires, their design abilities and their confidence. Each student is tasked with realising and exercising what might be termed their own architectural habitus. ${ }^{9}$ They do so through a step-by-step framework that provides local, operational specificity to ideas such as Donald Schön's notion of "reflection-in-action." 10 It results in a self-reflexive process of examination, validation and development of an individual's own ways of drawing, diagramming and modelling."

\footnotetext{
${ }^{7}$ David Mitchell in conversation.

8 Michael Davis, "Engaging in the Space of Representation," in Studio Teaching Symposium: A Two-Day Symposium Dedicated to Articulating and Sharing Best Practice Studio Pedagogy and Related Research, ed. Ralph Buck and Nuala Gregory (Auckland, New Zealand: Centre for New Zealand Art Research \& Discovery), I05-120.

9 Pierre Bourdieu, "Habitus," in Habitus: A Sense of Place, ed. Jean Hillier and Emma Rooksby (London: Ashgate, 2005), 43-49.

${ }^{10}$ Donald A. Schön, The Reflective Practitioner: How Professionals Think in Action (New York: Basic Books, 1983).

"See Davis, "Engaging in the Space of Representation" for the first review of this still unfolding model. It focused on unpacking one project vehicle through a discussion of the work of a single student.
} 
Emphases on each student developing their own critical media practices (and their theoretical implications) operate in stark contrast to prescribed and often prosaic requirements of client, site, brief, budget and timelines. We articulate this as a tension between the qualitative and the quantitative, not as a condition to be resolved but as a space of possibility.

\section{Learnings}

Our triple focus live project (as it has come to be known) has evolved in relation to these conditions. In responding to market demand for architectural speculation, locally the academy is being drawn out of the margins and into potentially difficult relations with both market and profession. Difficulties immediately apparent include the markets struggle to understand the peculiarities of both academy and profession and a lack of surety as to what to do with the speculative outcomes it desires once it has them. Meanwhile, the profession voices a desire for the academy to be more reflective of its self-perceived needs, but that desire doesn't extend to the point where its relationship to the market is challenged. For its part, the academy sees in the live project the potential for a harmonious nexus of architectural teaching, research and practice. Such a nexus is a "holy grail" of studio teaching, a goal our institutions set out for us in official documentation. But, as we near it, the question begs as to whether they are prepared for these kind of inevitably risky domains to operate. My sense is that they are not.

Further, it may actually be in the dissonance of these relations that opportunities for this triple focus model lie. Live projects run in our studio in this manner since 2007 have demonstrated the learning potential of bringing these relations to the fore and making the space thus established between parties the locus of design speculation. The benefits of acknowledging the inherent difficulties beyond the "petri-dish" of the studio are yet to be explored. Given a suitable project vehicle, if each party was to be problematised in relation to the other in an appropriately facilitated environment, might we see the kind of speculative project Liam produced in studio, subsequently developed, detailed and delivered onsite? Such an outcome is less likely to be produced through pursuing a happy nexus than it is through setting up academy, market and profession to act in critical, discursive ways with each other.

\section{Projecting the future of the triple focus live project}

The problem Alessandro, Liam and I encountered with Liam's project is a localised instance of a much larger issue embedded within the discipline. Despite the disappointment we felt as our attempts to take Liam's project to the next stage foundered, we recognised that to have reached the point where we were able to fail in this way we had more than met the aims of our design topic.

Amongst staff and students at the School there is no shortage of motivation to address the problem articulated above and so well illustrated by our experience of working with the Client. While that problem is widespread and enduring, so too is the potential it presents as an area for further research motivated by the desire for solutions. Two projects have crystallised and are in progress: a prequel of sorts which, in a didactic manner, sets out the pedagogical approach we have evolved since 2007; and a sequel looking at a model by which to transition academic projects to commercial environments to realisation onsite whilst privileging the ongoing learning of the students concerned. Initially named the Proto-Practice Unit, it manufactures an interface between academy, profession and market. It is a space of design research that incorporates real-world opportunities for students and recent graduates to develop practical knowledge and skills to support their shift from formal education to industry. The hope is that the unit will prove to be an alternative, generalisable model for the delivery of our triple focus live projects.

92 | The Journal of Public Space, 2(3), 2017 | Special Issue | ISSN 2206-9658

(C) Queensland University of Technology 